\title{
SOME QUESTIONS CONCERNING THE IODINE CONTENT IN MILK
}

\author{
E. ŠUCMAN ${ }^{1}$, Z. CVAK ${ }^{2}$, F. KALOUS ${ }^{3}$, O. SYNEK ${ }^{1}$
}

1 Department of Physics, Chemistry and Biochemistry, University of Veterinary Science, 61242 Brno

2 Dairy Research Institute, Prague

${ }^{3}$ Central State Veterinary Institute, Prague

Received April 12, 1983

\begin{abstract}
Sucman E., Z. Cvak, F. Kalous, O. Synek: Some Questions Concerning the Iodine Content in Milk. Acta Vet. Brno, 53, 1984: 65-69.

The determination of iodine level in milk from various regions of Czechoslovakia was carried out. Average iodine contents found were ranging from 140 to $225 \mu \mathrm{g} / \mathrm{l}$. A short-term application of Jodonal $M$ caused a marked increase in iodine concentration in milk from the average value $122 \mu \mathrm{g} / 1$ up to $831 \mu \mathrm{g} / 1$, the increased levels being sustained for 14 days from the beginning of application. A short pause followed by a new application of Jodonal $M$ induced again an increased iodine concentration in milk. This, however, lasted for a shorter period of time, the maximum achieved iodine concentration $(373 \mu \mathrm{g} / 1)$ being also considerably lower with regard to the first period.
\end{abstract}

Iodide, ion selective electrode, iodophores.

The concentration of iodine in various foodstuffs has been a subject of interest for a longer period of time, this being understandable when one takes into account the importance of this trace element for the biochemical functions of living organism. Milk, as a principal component of human nutrition, particularly of children, has been subjected to a close examination, especially during last years. The problems connected with the iodine content in milk have gained importance with the introduction of disinfectants, based on active iodine (so called iodophores), employed for disinfection of mammary glands of dairy cows as well as that of milking devices. All these measures were taken within the program of mastitis eradication. In this country several preparations have been commercialized under the trade name Jodonal (produced by Lachema).

The iodine content in milk, as published by various authors during last years, varies within a wide range from 10 to $4840 \mu \mathrm{g} / \mathrm{l}$ the most frequent concentration being found within $100-300 \mu \mathrm{g} / 1$ (Joerin and Bowering 1972; I warson and Ekman 1973; Barrios 1976; Dunsmore 1976; Kalous, Oliveriusová 1977; Bruhn, Franke 1978; Hemken 1978; Miles 1978; Šucman et al. 1978; Lacroix, Wong 1980; Sheldrake et al. 1980). The iodine level in milk depends on two important factors:

1. Intake of iodine in various amounts and in its various chemical forms in food.

2. External application of active iodine-based disinfectants (the application way, the treatment of mammary glands before milking, active iodine concentration in the applied preparation).

The problems connected with point 1 ) have been dealt with e. g. in works of Hilman and Curtis (1980), Hemken et al. (1981) or Laarveld et al. (1981). As to the use of iodophores, i. e. point 2), the reviews have been published e. d. by Hemken (1979), Piekacz (1979) and Wheeler (1979). All the authors agreed that the application of iodophores is always accompanied by the increase of iodine level in milk, the extent of this increase being, however, dependent on the type of preparation, the concentration of active iodine, the application form and other factors. The studies related to the application of iodophores and the iodine concentration in milk were also published by Iwarson and Ekman (1973), Barrios (1976), Sheldrake et al. (1980) or Hemken et al. (1981). 
The analytical method of iodine determination in milk is another very important question. A review published by Tušl (1981) concerns the possibilities of iodine determination in foodstuffs. Apart from the classical photometric method which is nowadays used mostly in automatic high performance continuous flow-through analysers of a great output (Barrios 1976; Sheldrake et al. 1980) there is a whole range of suitable methods of instrumental analysis such as the method of X-ray fluorescence (Crecelius 1975; Craven and Griffith 1977), radiochemical methods (see e. g. Ohmo 1980; Dermalj 1981), gas chromatography (Bakker 1977), differential pulse polarography (Propst 1977; Curtis and Hamming 1982). During last years the methods employing the iodide ion selective electrode have become particularly attractive due to their relative simplicity, rapidity, low equipment price and low running costs (Crecelius 1975; Craven; Griffith 1977; Bruhn and Franke 1978; Sucman et al. 1978; Lacroix and Wong 1980 and others).

It was the purpose of this work to obtain both informative values concerning the iodine level in milk coming from various regions of Czechoslovakia and to asses the degree to which iodine may be transferred to milk during a short term application of Jodonal $M$.

\section{Materials and Methods}

The samples of milk for the iodine level determination were randomly taken from the production lines of various dairies such as Lacrum Brno, Laktos Praha and PMV Works Opočno and Hradec Králové. The samples were taken in the course of the fourth quarter of 1979 and the first quarter of 1980 . No preservatives were used for milk and the iodine levels were determined within 24 hours at the latest, using the iodide ion selective electrode (Sucman et al. 1978). The samples were stored at ca $4{ }^{\circ} \mathrm{C}$ until analysed.

The experiment with a short-term application of Jodonal $M$ was carried out in July and 1980 on the state farm Smečno, locality Kladno. No iodophores had been applied on this farm before. Forty dairy cows were included in the experiment, 20 of this number serving as controls. The remaining 20 animals were treated with solutions of Jodonal $M$ (active iodine concentration $17 \mathrm{~g} / \mathrm{l}$ ) using the teat dipping method. The experiment was divided into four parts:

1. Preparatory phase - Iodine levels in milk of both groups were determined for 16 days prior to start of the experiment.

2. 1st application - For the period of 19 days the Jodonal $M$ solution of a given concentration was applied to the experimental group.

3. Interruption - The application as described above was interrupted for $\mathbf{8}$ days.

4. 2nd application - For the period of 6 days the Jodonal $M$ solution was reapplied as in the case of the first application.

The samples of bulk milk were taken twice a day from both groups of animals for the whole duration of experiment. Two parallel iodine determinations were carried out for each sample.

In the field, the experiment was carried out by Dairy Research Institute Prague and Central State Veterinary Institute Prague, the analyses being effected partially at the University of Veterinary Science, Brno, and partially at the above-mentioned laboratories. All calculations pertinent to the evaluation of analyses were carried out at the University of Veterinary Science, Brno using the programs that were worked out for the desk-top programmable computer EMG 666 (Hungary).

The measurements were carried out by means of ion selective electrodes, type $94-53$ (Orion Research, USA) and Crytur 53-27 (Monokrystaly, Turnov). Ag/AgCl electrodes 90-02 (Orion Research, USA) or OP-820 (Radelkis, Hungary) were used as reference electrodes. The potentiometric measurements were done on Orion Research Model 801A and on MV-87 Präcitronik (GDR) instruments. Chemicals used for making solutions were of analytical grade (Lachema).

\section{Results and Discussion}

The experimental results concerning the iodine content in milk of various regions of Czechoslovakia are summed up in Table 1 . As a relatively small amount of samples was analysed, these data should be considered as only informative values. They are, however, in good agreement with the iodine levels in raw milk as published elsewhere.

The experiment with an interrupted short-term application of Jodonal M may 
Table 1

Iodine levels in milk

\begin{tabular}{|c|c|c|c|c|}
\hline \multirow[b]{2}{*}{ Origin } & \multirow[b]{2}{*}{$n$} & \multirow[b]{2}{*}{$\begin{array}{c}\bar{c} \\
\mu g / 1\end{array}$} & \multicolumn{2}{|c|}{ Range } \\
\hline & & & $c_{\mu g / 1}^{c_{\min }}$ & $c_{\max / 1}^{c_{\max }}$ \\
\hline $\begin{array}{l}\text { Lacrum Brno } \\
\text { Laktos Praha } \\
\text { PMV Hradec Králové } \\
\text { PMV Opočno }\end{array}$ & $\begin{array}{l}20 \\
20 \\
20 \\
16\end{array}$ & $\begin{array}{l}167 \\
140 \\
225 \\
166\end{array}$ & $\begin{array}{r}75 \\
104 \\
155 \\
75\end{array}$ & $\begin{array}{l}360 \\
230 \\
270 \\
332\end{array}$ \\
\hline
\end{tabular}

$n$ number of analysed samples

$\bar{c}$ average determined concentration (mean of three parallel determinations)

$c_{\min }, c_{\max }$ minimal and maximal concentration found within the set of samples of common origin.

be evaluated as follows. Average iodine levels in milk of 40 dairy cows prior to our experiment was $122 \mu \mathrm{g} / \mathrm{l}$, the variation ranging from 60 to $175 \mu \mathrm{g} / 1$. The iodine concentration to $100 \mu \mathrm{g} / 1$ was found in $19 \%$ of analysed samples in this period; $101-150 \mu \mathrm{g} / 1$ was found in $63 \%$ of samples. During the actual experiment the iodine concentration in milk was within $40-196 \mu \mathrm{g} / \mathrm{l}$ (average $118 \mu \mathrm{g} / \mathrm{l}$ ) for the control group. The values to $100 \mu \mathrm{g} / 1$ were found in $39 \%$ of analysed samples while $45 \%$ of samples exhibited the values within the range $100-150 \mu \mathrm{g} / 1$.

As to the experimental group, there was a marked increase in iodine level in milk during the first application of Jodonal $M$ which lasted for 14 days. The maximum value of $831 \mu \mathrm{g} / \mathrm{l}$ was observed in the 7th day of application. A similar increase, although with a lower maximum value, appeared also during the second Jodonal $M$ application following the eight day pause. In this case the maximum value of $373 \mu \mathrm{g} / 1$ was noted already on the 3rd day of the experiment. It is believed that the faster onset of the maximum iodine concentration in milk during the second aplication of Jodonal $M$, as well as its lower value and a faster decline to the original value, is connected with the adaptation mechanism of dairy cows. These results are in good agreement with our preliminary experiment in which the iodophore was applied only once for a short time period (Synek et al. 1980). Here, the maximum concentration of iodine in milk was achieved in the 8th day of application, the return to initial state being observed after two-weeks application of the preparation. The time course of iodine concentration in milk of dairy cows is for both experimental groups shown in Fig. 1.

Also the literature data reported on a similar increase of iodine concentration in milk induced by the application of iodophores (Iwarson and Ekman 1973; Barrios 1976; Dunsmore 1976; Hemken 1979; Piekacz 1979; Sheldrake et al. 1980; Hemken et al. 1981). There are, however, no literature reports describing the influencing of iodine concentration by a short-term interruption of the iodophore application as reported in this paper.

The content of residues in milk and its effect is, in the case of iodine, important from the viewpoint of milk as the raw material for dairy products. It seems that the iodine content should be checked mainly in such cases when the milk is to be used for making various kinds of dried milk products for child nutrition. Also this work is hoped to be a contribution to the solution of this problem.

The authors thank MVDr. Horák, the director of District Veterinary Station Kladno for enabling the experiment and MVDr. Klaus of Regional Veterinary Station Kladno for a valuable experimental help. 


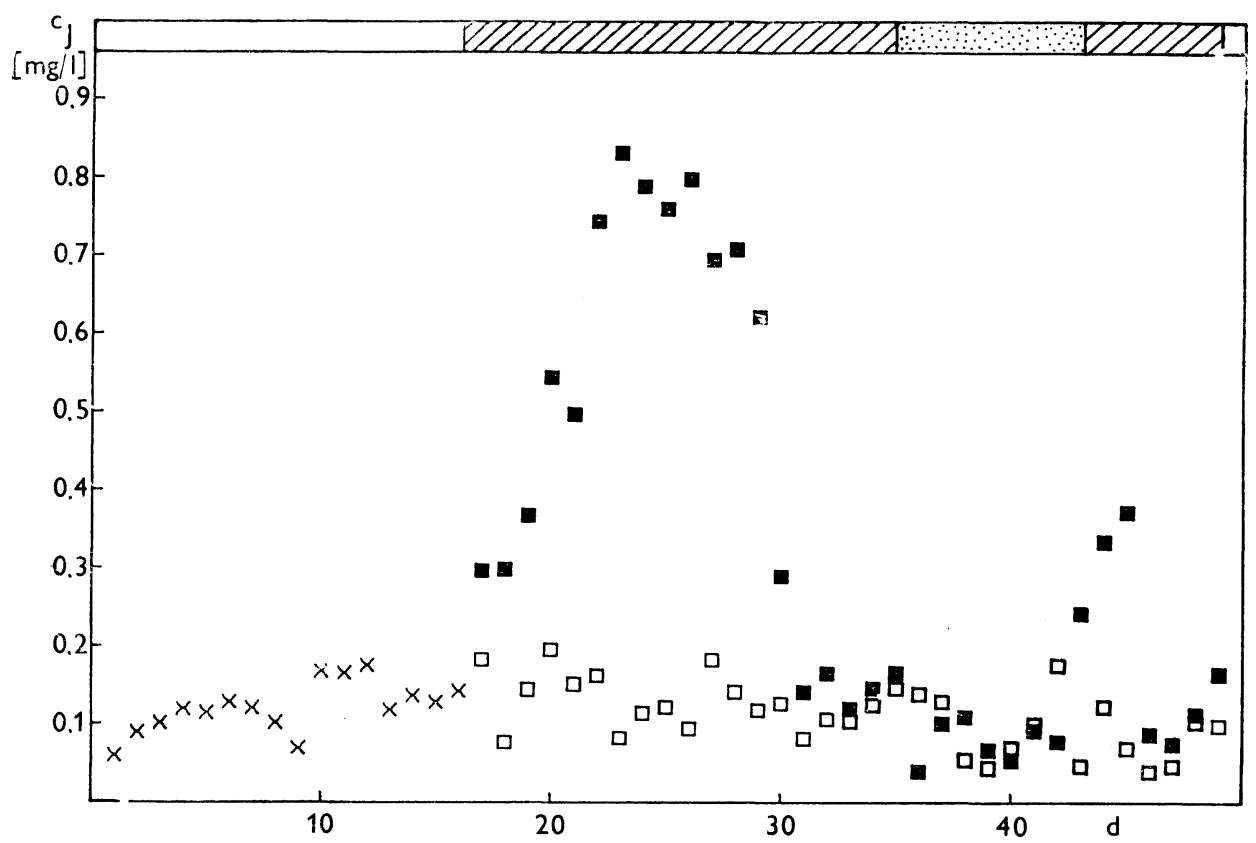

Fig. 1. Iodine concentration in milk during application of Jodonal $M$.

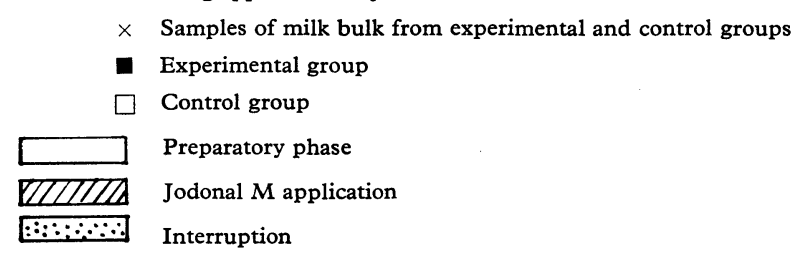

\section{K problematice obsahu jódu v mléce}

Bylo provedeno orientační stanovení obsahu jódu $\mathrm{v}$ mléce $\mathrm{z}$ různých oblastí ČSR. Průměrně nalezené obsahy se pohybovaly od $140 \mu \mathrm{g} / 1$ do $225 \mu \mathrm{g} / 1$. Př́i pokusu s krátkodobou aplikací Jodonalu $M$ bylo zjištěno, že koncentrace jódu v mléce se zvýšila z původní průměrné hodnoty $122 \mu \mathrm{g} / 1$ až na maximálně $831 \mu \mathrm{g} / 1$, př́ičemž zvýšené obsahy jódu byly nacházeny po dobu 14 dnů od počátku aplikace. Krátkodobé přerušení a opětná aplikace Jodonalu $M$ měly za následek nový vzrůst obsahu jódu v mléce, který však trval kratší dobu a dosažená maximální koncentrace $(373 \mu \mathrm{g} / \mathrm{l})$ byla oproti první výrazně nižší.

\section{К проблематике содержания иода в молоке}

Проводилось ориентировочное определение содержания иода в молоке из разных областей ЧСР. Найденные средние величины достигали пределюв от 140 мкг/л до 225 мкг/л. При кратковременном использовании иодонала М 
было установлено, что концентрация иода по сравнению с первоначальной средней величиной 122 мкг/л увеличилась до 831 мкг/л; повышенное содержание иода было установлено в течение двух недель с начала подачи. Кратковременное прекращение и последующая повторная подача иодонала $\mathrm{M}$ выразилась в новом увеличении содержания иода в молоке, которое однако длилось более короткое время и его максимальная концентрация (373 мкг/л) по сравнению с первоначальной была существенно ниже.

\section{References}

BAKKER, H. J.: Gas-Liquid Chromatographic Determination of Total Inorganic Iodine in Milk. J. Ass. Offic. Anal. Chem., 60, 1977: 1307-1309.

BARRIOS, J. V. G.: Jodgehalte in Milch, Harn und Blutserum bei Kühen durch Mineralstoffutter und Zitzentauchen mit Jodophoren. Inaugural-Dissertation Hannover 1976. Institut für Hygiene und Technologie der Milch der Tierärztlichen Hochschule Hannover.

BRUHN, J. C. - FRANKE, A. A.: An Indirect Method for the Estimation of the Iodine Content in Raw Milk. J. Dairy Sci., 61, 1978: 1557-1560.

CURTIS, A. R. - HAMMING, P.: Differential Pulse Polarographic Determination of Total Iodine in Milk. J. Ass. Offic. Anal. Chem., 65, 1982: 20-23.

DERMELJ, M.: Concentration Levels of Total Iodine in Environmental Biological Samples Determined by Neutron Activation Analysis. Vestn. Slov. Kem. Drus., 28, 1981: 213-223.

DUNSMORE, D. G.: Iodophors and Iodine in Dairy Products. The Iodine Content of Australian Dairy Products. Austr. J. Dairy Technol., 31, 1976: 125-129.

HEMKEN, R. W.: Factors that Influence the Iodine Content of Milk and meat. J. Anim Sci., 48, 1979: $981-985$.

HEMKEN, R. W. - FOX, J. D. - HICKS, C. L.: Milk Iodine Content as Influenced by Feed Sources and Santitizer Residues. J. Food Protect., 44, 1981: 476-479.

HILLMAN, D. - CURTIS, A. R.: Chronic Toxicity in Dairy Cattle: Blood Chemistry, Leukocytes and Milk Iodide. J. Dairy Sci., 63, 1980: 55-63.

IWARSON, K. - EKMAN, L.: The Effect of a Post-Milking Teat Dip on the Iodine Concentration of Bulk Herd Milk. Acta Vet. Scand., 14, 1973: 338-340.

JOERIN, M. M. - BOWERING, A.: Total Iodine Content of Cow's Milk. N. Z. J. Dairy Sci. Technol., 7, 1972: 155-159.

KALOUS, F. - OLIVERIUSOVÁ, J.: Stanovení obsahu jodu v mléce. Prům. Potravin, 28, 1977: $98-100$.

LAARVELD, B. - BROCKMAN, R. P. - CHRISTENSEN, D. A.: The Effects of the Level of Iodine in Canola Meal Concentrate on Milk Iodine and Thiocyanate Content and Thyroid Function in Dairy Cows. Can. J. Anim. Sci., 61, 1981: 625-632.

LACROIX, D. E. - WONG, N. P.: Determination of Iodine in Milk Using the Iodide Specific Ion Electrode and Its Application to Market Milk Samples. J. Food Protect., 43, 1980: 672-674.

MILES, P.: Determination of Iodide in Nutritional Beverage Products Using an Ion Selective Electrode. J. Ass. Offic. Anal. Chem., 61, 1978: 1366-1369.

OHNO, S.: Simple and Rapid Determination of Iodine in Milk by Radioactivation Analysis. Analyst, 105, 1980: 246-250.

PIEKACZ, H.: Jod w mleku po profilaktycznym stosowaniu preparatów jodoforowych. Bromat. Chem. Toksykol., 12, 1979: 1-6.

PROPST, R. C.: Cathodic Pulse Stripping Analysis of Iodine at the Parts-per-Billion Level. Anal. Chem., 49, 1977: 1197-1205.

SHELDRAKE, R. F.: Post-Milking Iodine Teat Skin Disinfectant. 3. Residues. J. Dairy Res., 47, 1980: 33-38.

ŠUCMAN, E. - ŠUCMANOVÁ, M. - SYNEK, O.: Potentiometrische Jodidgehaltsbestimmung in der Milch mit Hilfe einer ionenselektiven Elektrode. Z. Lebensm. Unters. - Forsch., 167, 1978: 5-6.

SYNEK, O. - ŠUCMAN, E. - ZIMA, S.: Biologicky aktuální prvky v mase a mléce. Project report. Brno, Vysoká škola veterinární 1980, 47 p.

TUŚL, J.: Stanovení jodu v potravinách. Chem. Listy, 75, 1981: 1233-1239.

WHEELER, S. M.: The Micro-Determination of Iodophors and Iodine in Milk. Austr. J. Dairy Technol., 34, 1979: 169-175. 